\title{
POLISH DENTAL ASSOCIATION AND NATIONAL PROGRAMME TO PROTECT ANTIBIOTICS WORKING GROUP RECOMMENDATIONS FOR ADMINISTRATION OF ANTIBIOTICS IN DENTISTRY
}

\author{
Tomasz Kaczmarzyk ${ }^{1,2}$, Karolina Babiuch ${ }^{2}$, Elżbieta Bołtacz-Rzepkowska ${ }^{3}$, Marzena Dominiak ${ }^{4}$, Tomasz Konopka ${ }^{5}$, \\ Mariusz Lipski ${ }^{6}$, Dorota Olczak-Kowalczyk ${ }^{7}$, Adam Szeląg ${ }^{8}$, Mariusz Szuta ${ }^{9}$, Waleria Hryniewicz ${ }^{10}$
}

'Department of Oral Surgery, Medical College, Jagiellonian University, Krakow, Poland

${ }^{2}$ Chair of Periodontics and Clinical Oral Pathology, Jagiellonian University, Krakow, Poland

${ }^{3}$ Department of Conservative Dentistry, Medical University of Łódź, Poland

${ }^{4}$ Chair of Oral Surgery, Medical University of Wrocław, Poland

${ }^{5}$ Chair of Periodontics, Medical University of Wrocław, Poland

${ }^{6}$ Chair of Preclinical Conservative Dentistry and Preclinical Endodontics, Pomeranian Medical University, Poland

${ }^{7}$ Chair of Paedodontics, Medical University of Warsaw, Poland

${ }^{8}$ Chair of Pharmacology, Medical University of Wrocław, Poland

${ }^{9}$ Chair of Cranio-maxillofacial, Oncological and Reconstructive Surgery, Medical College, Jagiellonian University, Krakow, Poland

${ }^{10}$ Department of Epidemiology and Clinical Microbiology, National Institute of Medicines, Poland

J Stoma 2018; 71, 6: 457-465

DOI: https://doi.org/10.5114/jos.2018.85560

This document shall serve as a list of recommendations of the Polish Dental Association and National Programme to Protect Antibiotics Working Group for antibiotic administration in dentistry.

There are two indications for antibiotic administration in dentistry: antibiotic prophylaxis (against surgical site infections or distant infections) and antibiotic treatment (of an already existing oral infection). It is very important to emphasize that maintaining proper oral hygiene and using aseptic and antiseptic techniques are of paramount importance for prevention of oral infections, whereas causative dental treatment constitutes an essential step in their treatment. Antibiotic administration is no substitute for the foregoing.

The following recommendations have been formulated on the basis of the available scientific data regarding specific areas of dentistry. They do not, however, override in any way whatsoever the individual responsibility of dentists to make appropriate and accurate decisions in consideration of each patient's health condition and in consultation with that patient or the patient's caregiver where appropriate or necessary. It is also the dentist's responsibility to verify the rules and regulations applicable to medications at the time of prescription.

The present recommendations have been mostly formulated on the basis of the consensus of opinion of the experts and/or of the results of retrospective studies (level of evidence $\mathrm{C}$ ) or data derived from single randomized clinical trials (level B) as data derived from multiple randomized clinical trials or meta-analyses (level A) are available only for very few indications for antibiotic administration in dentistry.

Members of the Working Group preparing these recommendations stress that antibiotics are significantly misused and overused in dentistry, despite the fact that an alarming increase in bacterial resistance to antibiotics is observed, and it constitutes one of the major problems of contemporary medicine. Consequently, whenever antibiotic administration is considered, a dentist should weigh the potential benefits and risks resulting from this decision, since in dentistry in most cases individual (for a patient) and collective (for a society) risks of antibiotic administration outweigh its possible benefits (prevention or treatment of infection). 


\section{POLISH DENTAL ASSOCIATION AND NATIONAL PROGRAMME TO PROTECT ANTIBIOTICS WORKING GROUP RECOMMENDATIONS FOR ANTIBIOTICS ADMINISTRATION IN DENTISTRY}

\section{RECOMMENDATIONS FOR ANTIBIOTIC PROPHYLAXIS AGAINST SURGICAL SITE INFECTIONS}

\author{
GENERAL RECOMMENDATIONS FOR ANTIBIOTIC PROPHYLAXIS \\ AGAINST SURGICAL SITE INFECTIONS IN ORAL AND

\section{MAXILLOFACIAL SURGERY}

- Maintaining proper oral hygiene and using aseptic and antiseptic techniques are of paramount importance for prevention of oral and maxillofacial infections.

- Routine administration of antibiotic prophylaxis in immunocompetent patients is not recommended; the decision of administration of antibiotic prophylaxis should be very prudent.

- Antibiotic prophylaxis is recommended in immunocompromised $^{1}$ patients, in consultation with the attending physician.

- Antibiotic prophylaxis should be administered 30-60 minutes before commencement of surgery.

- For prophylaxis, it is recommended to administer only one dose of an antibiotic (one-shot prophylaxis) and no further doses after completion of surgery should be administered, with the exceptions presented in certain detailed recommendations (ultra-short, short-term and long-term prophylaxis).

- Unless otherwise specified in the detailed recommendation, for antibiotic prophylaxis in dentistry amoxicillin without clavulanic acid in a single dose of $2000 \mathrm{mg}$ is recommended; patients allergic to penicillins should be given cefazolin ${ }^{2}$ in a single dose of $1000 \mathrm{mg}$ or clindamycin in a single dose of $600 \mathrm{mg}$.

- Unless otherwise specified in the detailed recommendation, for antibiotic prophylaxis in pediatric patients amoxicillin without clavulanic acid in a single dose of $50 \mathrm{mg} / \mathrm{kg}$ is recommended; patients allergic to penicillins should be given cefazolin ${ }^{2}$ in a single dose of $50 \mathrm{mg} / \mathrm{kg}$ or clindamycin in a single dose of $20 \mathrm{mg} / \mathrm{kg}$.

\footnotetext{
${ }^{1}$ An immunocompromised patient is usually a patient: (1) affected with hematological or congenital/acquired immunodeficiency (e.g. hypogammaglobulinemia, lymphoma, leukemia, Chediak-Higashi syndrome, DiGeorge syndrome, HIV+ with CD4 count $<100 / \mathrm{mm}^{3}$ and neutrophil count $<500 / \mathrm{mm}^{3}$, (2) on immunosuppressive, cytotoxic or steroid therapy (e.g. transplant or cancer patients, systemic connective tissue disease), (3) affected with chronic and unregulated metabolic disease (e.g. poor glycemic control diabetes, hepatic cirrhosis, renal insufficiency, malnutrition).

${ }^{2}$ Cephalosporins should not be used in patients with a history of anaphylaxis, angio-edema, or urticaria after intake of penicillins.
}

\section{SPECIFIC RECOMMENDATION FOR ANTIBIOTIC PROPHYLAXIS}

AGAINST SURGICAL SITE INFECTIONS IN THIRD MOLAR SURGERY

- Routine administration of antibiotic prophylaxis in third molar surgery in immunocompetent patients is not recommended; antibiotic prophylaxis should be considered in immunocompromised patients in consultation with the attending physician or whenever it is necessary to perform surgery in the course of acute pericoronitis.

\section{SPECIFIC RECOMMENDATION FOR ANTIBIOTIC PROPHYLAXIS}

\section{AGAINST SURGICAL SITE INFECTIONS IN IMPLANT SURGERY}

- Routine administration of antibiotic prophylaxis in implant surgery in immunocompetent patients is not recommended; antibiotic prophylaxis should be considered in immunocompromised patients in consultation with the attending physician.

- It is recommended to consider administration of antibiotic prophylaxis in implant procedures involving bone grafting.

\section{SPECIFIC RECOMMENDATION FOR ANTIBIOTIC PROPHYLAXIS}

\section{AGAINST SURGICAL SITE INFECTIONS IN BONE GRAFTING SURGERY}

- It is recommended to consider administration of antibiotic prophylaxis in bone grafting surgery.

\section{SPECIFIC RECOMMENDATION FOR ANTIBIOTIC PROPHYLAXIS}

\section{AGAINST SURGICAL SITE INFECTIONS IN DENTO-ALVEOLAR SURGERY}

- Routine administration of antibiotic prophylaxis in dento-alveolar surgery (e.g. surgical extraction, cystectomy or intraosseous bone tumor removal) in immunocompetent patients is not recommended; antibiotic prophylaxis should be considered in immunocompromised patients, in consultation with the attending physician.

- It is recommended to administer one dose of antibiotic prophylaxis in case of dento-alveolar surgery involving exposure of antral or nasal mucosa as well as involving removal of extensive bone cysts and tumors.

\section{SPECIFIC RECOMMENDATION FOR ANTIBIOTIC PROPHYLAXIS}

\section{AGAINST SURGICAL SITE INFECTIONS IN ENDODONTIC SURGERY}

- Routine administration of antibiotic prophylaxis in endodontic surgery in immunocompetent patients 
is not recommended; antibiotic prophylaxis should be considered in immunocompromised patients, in consultation with the attending physician.

\section{SPECIFIC RECOMMENDATION FOR ANTIBIOTIC PROPHYLAXIS}

\section{AGAINST SURGICAL SITE INFECTIONS IN PERIODONTAL SURGERY}

- Routine administration of antibiotic prophylaxis in periodontal surgery in immunocompetent patients is not recommended; antibiotic prophylaxis should be considered in immunocompromised patients, in consultation with the attending physician.

\section{SPECIFIC RECOMMENDATION FOR ANTIBIOTIC PROPHYLAXIS}

\section{AGAINST SURGICAL SITE INFECTIONS IN ORTHOGNATHIC SURGERY}

- It is recommended to administer antibiotic prophylaxis in orthognathic procedures with intraoral surgical approach or involving exposure of antral or nasal mucosa.

- In this indication IV ampicillin/sulbactam administration 30-60 minutes before commencement of surgery is recommended: in adults in a dose of $1500 \mathrm{mg}$ and in children in a dose of $50 \mathrm{mg} / \mathrm{kg}$, and:

- during prolonged (>4h) procedures another dose of antibiotic should be administered;

- in extensive procedures involving high blood loss (> $1000 \mathrm{ml}$ ) it is recommended to continue administration of antibiotic prophylaxis every 6-8 h during the first $24 \mathrm{~h}$ after the first dose (ultra-short prophylaxis).

- Patients allergic to penicillin should be given clindamycin in a dose of $600 \mathrm{mg}$ (adults) or $20 \mathrm{mg} / \mathrm{kg}$ (children), according to the abovementioned design.

\section{SPECIFIC RECOMMENDATION FOR ANTIBIOTIC PROPHYLAXIS}

\section{AGAINST SURGICAL SITE INFECTIONS IN MAXILLOFACIAL SURGERY}

- Routine administration of antibiotic prophylaxis in soft tissue procedures involving extraoral surgical approach (e.g. parotidectomy) or in neck dissections without opening of airways is not recommended.

- Antibiotic prophylaxis is recommended in maxillofacial procedures involving: bone resection, free or pediculated flaps, neck dissections with opening of airways and bone grafting.

- In these indications IV ampicillin/sulbactam administration 30-60 minutes before commencement of surgery is recommended: in adults in a dose of $1500 \mathrm{mg}$ and in children in a dose of $50 \mathrm{mg} / \mathrm{kg}$, and:

- during prolonged (> $4 \mathrm{~h}$ ) procedures another dose of antibiotic should be administered;

- in extensive procedures involving high blood loss (> $1000 \mathrm{ml}$ ) it is recommended to continue administration of antibiotic prophylaxis every 6-8 $\mathrm{h}$ during the first $24 \mathrm{~h}$ after the first dose (ultra-short prophylaxis).
- Patients allergic to penicillin should be given clindamycin in a dose of $600 \mathrm{mg}$ (adults) or $20 \mathrm{mg} / \mathrm{kg}$ (children), according to the abovementioned design.

\section{SPECIFIC RECOMMENDATION FOR ANTIBIOTIC PROPHYLAXIS}

\section{AGAINST SURGICAL SITE INFECTIONS IN PATIENTS}

\section{ON ANTIRESORPTIVE/ANTIANGIOGENIC THERAPY}

\section{OR WITH A HISTORY OF MAXILLOFACIAL RADIOTHERAPY}

- It is recommended to administer antibiotic prophylaxis in patients taking bisphosphonates, denosumab or bevacizumab before any surgical procedure involving bone surgery (e.g. exodontia, dento-alveolar surgery, endodontic or periodontal surgery); antibiotic therapy should be initiated one day before surgery and continued until the $3^{\text {rd }}$ postoperative day (short-term prophylaxis), with the exception of cases of concurrent risk factors for medication-related osteonecrosis of the jaw (therapy with zoledronic acid, intravenous route of bisphosphonate administration, therapy $>3$ years, previous episode of osteonecrosis of the jaw) where antibiotic prophylaxis should be continued up until the $14^{\text {th }}$ postoperative day (long-term prophylaxis).

- It is recommended to administer antibiotic prophylaxis in patients with a history of maxillofacial radiotherapy before any surgical procedure involving bone surgery (e.g. exodontia, dento-alveolar surgery, endodontic or periodontal surgery); antibiotic therapy should be initiated one day before surgery and continued until the $3^{\text {rd }}$ postoperative day (short-term prophylaxis).

- In these indications amoxicillin/clavulanic acid is recommended: in adults $-1000 \mathrm{mg}(875 \mathrm{mg}+125 \mathrm{mg})$ BID and in children $-(45 \mathrm{mg}+6.4 \mathrm{mg}) / \mathrm{kg} /$ day in 2 divided doses; patients allergic to penicillins should be medicated with clindamycin: in adults $300 \mathrm{mg}$ TID and in children $-8-16 \mathrm{mg} / \mathrm{kg} /$ day in 3-4 divided doses.

\section{SPECIFIC RECOMMENDATION FOR ANTIBIOTIC PROPHYLAXIS}

\section{AGAINST INFECTIONS OFWOUNDS OF FACIAL SKIN OR ORAL MUCOSA}

- Antibiotic prophylaxis against infections of minor, fresh $^{3}(<12 \mathrm{~h})$ wounds in immunocompetent patients is not recommended.

- Antibiotic prophylaxis is recommended in the case of wounds following:

- blunt injury,

- gunshot, bite or avulsion injury,

- injury inflicted with dirty object,

- dirty wounds, > 12 h old with no previous dressing,

\footnotetext{
${ }^{3}$ Due to the very good blood supply of head and neck tissues, wounds in these areas usually maintain their sterility for longer periods than in
} other anatomical sites. 
- injuries in immunocompromised patients, in consultation with the attending physician.

- In these indications it is recommended to administer a single dose of either IV ampicillin/sulbactam: adults $-1500 \mathrm{mg}$, children $-50 \mathrm{mg} / \mathrm{kg}$ or PO amoxicillin/clavulanic acid: adults - $2000 \mathrm{mg}$, children $(45 \mathrm{mg}+6.4 \mathrm{mg}) / \mathrm{kg}$.

\section{SPECIFIC RECOMMENDATION FOR ANTIBIOTIC PROPHYLAXIS AGAINST INFECTIONS OF BONE FRACTURES}

- Antibiotic prophylaxis against infection of closed fractures (e.g. fractures of condyle or mandible ramus) in immunocompetent patient is not recommended, insofar as conservative or surgical treatment involving the extraoral approach is applied.

- Antibiotic prophylaxis is recommended in the case of:

- open fractures (e.g. mandible body fracture),

- fractures with delayed treatment,

- pathologic fractures,

- surgically treated fractures involving the intraoral approach,

- comminuted fractures,

- fractures involving nasal or paranasal sinuses mucosa exposure,

- fractures in immunocompromised patients, in consultation with the attending physician.

- In these indications clindamycin in a single dose of $600 \mathrm{mg}$ in adults or $20 \mathrm{mg} / \mathrm{kg}$ in children is recommended.

\section{RECOMMENDATIONS FOR ANTIBIOTIC PROPHYLAXIS AGAINST DISTANT INFECTIONS}

\section{RECOMMENDATION FOR ANTIBIOTIC PROPHYLAXIS AGAINST}

\section{INFECTIVE ENDOCARDITIS (IE) FOLLOWING DENTAL PROCEDURES ${ }^{4}$}

- Strict oral hygiene and frequent dental follow-up in IE high-risk patients are decidedly recommended.

- It is recommended that patients with cardiac conditions at the highest risk of IE, including:

- patients with any prosthetic valve, including a transcatheter valve, or those in whom any prosthetic material was used for cardiac valve repair;

- patients with congenital heart disease (CHD):

- any type of cyanotic CHD,

- any type of CHD repaired with a prosthetic material, whether placed surgically or by percutaneous techniques, up to 6 months after the procedure or lifelong if residual shunt or valvular regurgitation remains;

\footnotetext{
${ }^{4}$ This recommendation conforms to the 2015 Guidelines of European Society of Cardiology for the management of infective endocarditis (Habib, et al. 2015 ESC Guidelines for the management of infective endocarditis. Eur Heart J 2015; 36: 3075-3123).
}

- patients with a previous episode of IE,

- 30-60 minutes before commencement of a dental procedure requiring manipulation of the gingival or periapical region of the teeth or perforation of oral mucosa should receive:

- PO amoxicillin (without clavulanic acid) or IV ampicillin (without sulbactam): adults $2000 \mathrm{mg}$, children - $50 \mathrm{mg} / \mathrm{kg}$;

- in patients allergic to penicillins one of the following should be administered 30-60 minutes before the procedure:

- PO or IV clindamycin: adults - $600 \mathrm{mg}$, children $-20 \mathrm{mg} / \mathrm{kg}$,

- IV cefalexin ${ }^{5}$ : adults - $2000 \mathrm{mg}$, children $50 \mathrm{mg} / \mathrm{kg}$,

- IV cefazolin ${ }^{5}$ : adults - $1000 \mathrm{mg}$, children $50 \mathrm{mg} / \mathrm{kg}$,

- IV ceftriaxone ${ }^{5}$ : adults - $1000 \mathrm{mg}$, children $50 \mathrm{mg} / \mathrm{kg}$.

- Antibiotic prophylaxis is not recommended in any other congenital or acquired heart disease or in patients with a history of myocardial or cerebral infarction, bypass surgery or patients with a implanted pacemaker.

- Antibiotic prophylaxis is not recommended for local anesthetic injections in non-infected tissues, treatment of dental caries, removal of sutures, placement or adjustment of removable prosthodontic or orthodontic appliances or braces and following the shedding of deciduous teeth or trauma to the lips or oral mucosa.

\section{RECOMMENDATION FOR ANTIBIOTIC PROPHYLAXIS AGAINST}

PERIPROSTHETIC JOINT INFECTIONS FOLLOWING DENTAL

\section{PROCEDURES}

- Antibiotic prophylaxis in patients with artificial joint prostheses before any dental procedure is not recommended.

\section{RECOMMENDATION FOR ANTIBIOTIC THERAPY OF ODONTOGENIC INFECTIONS}

- Antibiotic therapy is not recommended for treatment of limited, non-spreading odontogenic infections which are not associated with the impaired general state in immunocompetent patients.

- Local treatment consisting of pus drainage and extraction or endodontic therapy of a causative tooth is fundamental for treatment of odontogenic infections.

- Antibiotic therapy of odontogenic infections is indicated in immunocompromised patients (in consul-

${ }^{5}$ Cephalosporins should not be used in patients with a history of anaphylaxis, angio-edema, or urticaria after intake of penicillins. 
tation with the attending physician where possible); however, in immunocompetent patients antibiotic therapy is only complementary to the local treatment and should be administered solely in patients with an impaired general state (high fever, malaise, vertigo, dehydration, tachycardia) or in cases of inflammation involving extraoral anatomical spaces with a tendency to spread.

- Only in exceptional circumstances, when there is no possibility of immediate causative treatment (e.g. high trismus, lack of efficacy of local anaesthesia), may administration of antibiotic to reduce inflammation be considered; however, causative treatment should be implemented without any further delay.

- In the case of empirical antibiotic therapy (without results of laboratory testing for bacterial sensitivity) amoxicillin without clavulanic acid should be administered as the first-line therapy (Table 1).
- Clindamycin is recommended only in patients allergic to penicillins, and it should be administered every 6-8 h (but not every $12 \mathrm{~h}$ ), and a single dose should not exceed $300 \mathrm{mg}$ (Table 1 ).

- It is recommended that every patient treated with antibiotic should be followed up on a regular basis and the first follow-up should take place not later than 48-72 h after commencement of antibiotic therapy.

- Antibiotic therapy should be continued until significant improvement in the patient's general state (decrease of body temperature, wellbeing), in which case antibiotic therapy should be ceased.

- It is recommended that if there is no improvement in the patient's general state after $72 \mathrm{~h}$ of antibiotic therapy a second-line antibiotic should be considered, and the efficacy of drainage should be re-evaluated.

- The list of recommended antibiotics in empirical therapy is annexed to this recommendation (Table 1).

TABLE 1. Antibiotics recommended for treatment of odontogenic infections

\begin{tabular}{|c|c|c|c|}
\hline \multirow{2}{*}{\multicolumn{2}{|c|}{ First-line therapy }} & \multirow[t]{2}{*}{ Adults } & \multirow[t]{2}{*}{ Children } \\
\hline & & & \\
\hline Oral administration & Amoxicillin & $\begin{array}{c}500 \text { mg TID or } 750-1000 \text { mg BID; } \\
\text { TID scheme usually shows greater } \\
\text { effectiveness }\end{array}$ & $\begin{array}{l}\text { children up to } 40 \mathrm{~kg}: 20-40 \mathrm{mg} / \mathrm{kg} / \text { day } \\
\text { in } 3 \text { divided doses } \\
\text { children over } 40 \mathrm{~kg} \text { : as in adults }\end{array}$ \\
\hline Parenteral administration & Ampicillin & $500 \mathrm{mg}$ QID & $\begin{array}{l}\text { children up to } 20 \mathrm{~kg}: 12.5 \mathrm{mg} / \mathrm{kg} \text { QID } \\
\text { children over } 20 \mathrm{~kg} \text { : as in adults }\end{array}$ \\
\hline \multicolumn{4}{|l|}{ Second-line therapy* } \\
\hline \multirow[t]{2}{*}{ Oral or parenteral administration } & $\begin{array}{l}\text { Amoxicillin/ } \\
\text { Clavulanic acid }\end{array}$ & $875 \mathrm{mg}+125 \mathrm{mg}$ BID & $\begin{array}{l}\text { children up to } 40 \mathrm{~kg} \text { : }(45 \mathrm{mg}+6.4 \mathrm{mg}) / \mathrm{kg} / \text { day } \\
\text { in } 2 \text { divided doses } \\
\text { children over } 40 \mathrm{~kg} \text { : as in adults }\end{array}$ \\
\hline & Clindamycin & $150 \mathrm{mg}$ QID or $300 \mathrm{mg} \mathrm{TID}^{\dagger}$ & $\begin{array}{l}\text { children up to } 14 \text { years of age: } 8-16 \mathrm{mg} / \mathrm{kg} / \text { day } \\
\text { in 3-4 divided doses } \\
\text { children over } 14 \text { years of age: as in adults }\end{array}$ \\
\hline Parenteral administration & Ampicillin/Sulbactam & $500 \mathrm{mg}+250 \mathrm{mg}$ TID or QID & $(100 \mathrm{mg}+50 \mathrm{mg}) / \mathrm{kg} /$ day in 3-4 divided doses \\
\hline \multicolumn{4}{|l|}{ Alternative therapy $^{* *}$} \\
\hline \multirow[t]{4}{*}{ Oral administration } & Cefuroxime axetil & $500 \mathrm{mg}$ BID & $\begin{array}{l}\text { children over } 3 \text { months of age: } 20 \mathrm{mg} / \mathrm{kg} / \text { day } \\
\text { in } 2 \text { divided doses } \\
\text { children over } 12 \text { years of age: } 250 \mathrm{mg} \text { BID }\end{array}$ \\
\hline & Spiramycin & $3,000,000$ IU BID & $150,000 \mathrm{lU} / \mathrm{kg} /$ day in 2-3 divided doses \\
\hline & Clarithromycin & $250 \mathrm{mg}$ BID & $\begin{array}{l}\text { body mass up to } 8 \mathrm{~kg}: 7.5 \mathrm{mg} / \mathrm{kg} \text { BID } \\
\text { body mass } 8-11 \mathrm{~kg}: 62.5 \mathrm{mg} \text { BID } \\
\text { body mass } 12-19 \mathrm{~kg}: 125 \mathrm{mg} \text { BID } \\
\text { body mass } 20-30 \mathrm{~kg}: 187.5 \mathrm{mg} \text { BID } \\
\text { body mass over } 30 \mathrm{~kg}: \text { as in adults }\end{array}$ \\
\hline & Azithromycin & $500 \mathrm{mg} Q \mathrm{D}$ & 10 mg/kg/day QD \\
\hline Oral or parenteral administration & $\begin{array}{l}\text { Metronidazole (usually } \\
\text { co-administered with } \\
\text { amoxicillin or penicillin V) }\end{array}$ & $500 \mathrm{mg}$ TID & $\begin{array}{l}\text { up to } 12 \text { years of age: } 7.5 \mathrm{mg} / \mathrm{kg} \text { TID } \\
\text { over } 12 \text { years of age: as in adults }\end{array}$ \\
\hline
\end{tabular}

${ }^{*}$ Recommended whenever first-line therapy is difficult, improper or contraindicated or when there is no response to first-line therapy after 48-72h.

**Recommended whenever contraindications for first- and second-line therapy occur.

${ }^{+}$Single oral dose of clindamycin should not exceed $300 \mathrm{mg}$ and intervals between doses should not be longer than $8 \mathrm{~h}$; single oral dose of clindamycin over $450 \mathrm{mg}$ should be reserved for parenteral administration for treatment of severe and life-life-threatening infections. 


\section{RECOMMENDATION FOR ANTIBIOTIC THERAPY IN PERIODONTITIS AND PERIIMPLANTITIS}

- Routine administration of antibiotics for the treatment of periodontitis and peri-implantitis in immunocompetent patients is not recommended; mechanical therapy involving removal of supra- and subgingival deposits of calculus and dental plaque by means of scaling and root planing (SRP) plays a fundamental role in periodontal therapy.

- Systemic antibiotic administration is recommended in patients with acute symptoms of the periodontal disease such as multiple periodontal abscesses and necrotizing periodontal diseases with systemic involvement (high fever, malaise, vertigo, dehydration, tachycardia).

- Administration of antibiotic therapy should also be considered in the case of A. actinomycetemcomitans and/or $P$. gingivalis infection in the course of refractory periodontitis in stage IV of the disease (according to the 2017 classification of periodontal and peri-implant diseases)[11].

- It is recommended to consider systemic antibiotic administration for treatment of periodontitis and peri-implantitis in immunocompromised patients (in consultation with the attending physician).

- Administration of systemic antimicrobials should be preceded by culture and sensitivity microbiological testing whenever possible.

- In the case of empirical antibiotic therapy of multiple periodontal abscesses amoxicillin/clavulanic acid is recommended: in adults and children over $40 \mathrm{~kg}$ - $1000 \mathrm{mg}$ (875 mg + $125 \mathrm{mg}$ ) BID for 5 days, and in children up to $40 \mathrm{~kg}-(45 \mathrm{mg}+6.4 \mathrm{mg}) / \mathrm{kg} /$ day in two divided doses for 5 days; in patients allergic to penicillins azithromycin is recommended: in adults $500 \mathrm{mg}$ QD for 3 days, and in children - $10 \mathrm{mg} / \mathrm{kg}$ QD for 3 days; in this indication administration of antibiotic should be simultaneous with mechanical therapy.

- In the case of empirical antibiotic therapy of necrotizing periodontal diseases administration of metronidazole is recommended: in adults and children over the age of $12-250 \mathrm{mg}$ TID for 7 days, and in children up to 12 years of age $-7.5 \mathrm{mg} / \mathrm{kg}$ TID for 7 days; in this indication administration of antibiotic should be simultaneous with mechanical therapy.

- In the case of empirical antibiotic therapy of stage IV of periodontitis, co-administration of amoxicillin (without clavulanic acid) and metronidazole for 7 days is recommended according to the following scheme:

- in adults and children over $40 \mathrm{~kg}$ amoxicillin should be administered in a dose of $500 \mathrm{mg}$ TID, and in children up to $40 \mathrm{~kg}-40 \mathrm{mg} / \mathrm{kg} /$ day in 3 divided doses,

- in adults and children over the age of 12 metronidazole should be administered in a dose of
$250 \mathrm{mg}$ TID, and in children up to 12 years of age $-7.5 \mathrm{mg} / \mathrm{kg}$ TID,

- in patients allergic to penicillins, administration of metronidazole alone according to the above scheme is recommended,

- it is recommended to commence antibiotic therapy on the day of completion of mechanical therapy.

\section{RECOMMENDATIONS FOR THE USE OF ANTIBIOTICS IN ENDODONTICS ${ }^{6}$}

\section{RECOMMENDATION FOR SYSTEMIC ANTIBIOTIC PROPHYLAXIS}

\section{IN ENDODONTICS}

- Routine administration of antibiotic prophylaxis before root canal treatment in immunocompetent patients is not recommended.

- Antibiotic prophylaxis before root canal treatment is recommended only in:

- immunocompromised patients, after considering the state and control of the disease, risk of infection-related complications and risk of adverse drug reactions,

- patients with cardiac conditions at the highest risk of IE,

- patients with previous radiotherapy of the maxillofacial region.

- In the event of a decision of antibiotic prophylaxis administration before root canal treatment, antibiotic selection and dosing should follow "Recommendation for antibiotic prophylaxis against infective endocarditis (IE) following dental procedures".

\section{RECOMMENDATION FOR SYSTEMIC ANTIBIOTIC THERAPY}

\section{IN ENDODONTICS}

- Local treatment plays a fundamental role in therapy of endodontic infections, whereas adjunctive systemic antibiotic treatment is indicated only in the following conditions:

- acute periapical abscess in immunocompromised patients,

- acute periapical abscess with systemic involvement (high fever, malaise, vertigo, dehydration, tachycardia) or advanced local signs (lymphadenopathy, extensive swelling, severe trismus), irrespective of patient's immunological status,

- progressive infections (rapid onset of severe infection in less than $24 \mathrm{~h}$, cellulitis/phlegmon, acute osteomyelitis).

\footnotetext{
${ }^{6}$ Recommendations of Polish Dental Association for the use of antibiotics in endodontics are in line with the position statement of the European Society of Endodontology from the year 2017 (Segura-Egea, et al. European Society of Endodontology position statement: the use of antibiotics in endodontics. Int Endod J 2017; 51: 20-25).
} 
- Adjunctive systemic antibiotic treatment is not recommended in the following conditions:

- symptomatic irreversible pulpitis (pain with no other signs and symptoms of infection),

- pulp necrosis,

- symptomatic periapical periodontitis (spontaneous pain, pain to percussion and biting, widening of periodontal ligament space),

- chronic periapical periodontitis/chronic periapical abscess (periapical radiolucency, sinus tract),

- acute periapical abscess without systemic involvement (normal body temperature, patient well-being) and with mild localized symptoms (e.g. localized swelling).

- In the event of a decision of antibiotic therapy of endodontic infection, antibiotic selection and dosing should follow "Recommendations for antibiotic therapy of odontogenic infections".

\section{RECOMMENDATION FOR LOCAL ANTIBIOTIC APPLICATION IN}

\section{ENDODONTICS}

- Antibiotics are not recommended in pulp capping procedures or for root canal disinfection.

- Due to the fact that the antibiotic mixture composed of ciprofloxacin, metronidazole and minocycline known as triple antibiotic paste (TAP) may cause dentine discoloration and that there is a lack of strong evidence to support the use of antibiotics in regenerative endodontic procedures, the use of calcium hydroxide for pulp revascularization is recommended.

\section{RECOMMENDATION FOR THE USE OF ANTIBIOTICS IN DENTAL TRAUMA ${ }^{7}$}

- Routine administration of antibiotics is not recommended in the following conditions:

- crown fracture, root fracture, concussion, subluxation and partial luxation of a permanent tooth,

- trauma to primary dentition.

- Avulsion of a permanent tooth is an indication for systemic antibiotic administration, in which case tetracycline is recommended in the dose of $25 \mathrm{mg} / \mathrm{kg} /$ day

\footnotetext{
${ }^{7}$ Recommendations of the Polish Dental Association for the use of antibiotics in dental traumatology are in line with guidelines of the International Association of Dental Traumatology (Diangelis, et al. International Association of Dental Traumatology guidelines for the management of traumatic dental injuries: 1 . Fractures and luxations of permanent teeth. Dent Traumatol 2012; 28: 2-12; Andersson, et al. International Association of Dental Traumatology guidelines for the management of traumatic dental injuries: 2 . Avulsion of permanen teeth. Dent Traumatol 2012; 28: 88-96; Malmgren, et al. International Association of Dental Traumatology guidelines for the management of traumatic dental injuries: Injuries in the primary dentition. Dent Traumatol 2012; 28: 174-82)
}

for the first week after the replantation procedure; due to the risk of discoloration of permanent teeth, in non-penicillin-allergic children up to 12 years of age phenoxymethylpenicillin (penicillin V) or amoxicillin (without clavulanic acid) should be considered in an appropriate dose for the age and weight; in the case of replantation of an immature tooth, topical application of antibiotic (minocycline or doxycycline, $1 \mathrm{mg}$ per $20 \mathrm{ml}$ of saline for $5 \mathrm{~min}$ ) on the root surface before replantation should be considered.

- The decision about the systemic use of an antibiotic may be dictated by associated injuries and the patient's medical status.

\section{References}

1. Abel SN, Croser D, Fischman SL, et al. Principles of oral health management for the HIV/AIDS patient. 2000 edition. Dental Alliance for AIDS/HIV Care. Philadelphia: http://www.aids-ed. org/pdf/curricula/Princ_Oral_Health_HIV.pdf

2. Abu-Ta'a M. Adjunctive systemic antimicrobial therapy vs asepsis in conjunction with guided tissue regeneration: a randomized, controlled clinical trial. J Contemp Dent Pract 2016; 17: 3-6.

3. Albrektsson T, Dahlin C, Jemt T, et al. Is marginal bone loss around oral implants the result of a provoked foreign body reaction? Clin Implant Dent Rel Res 2014; 16: 155-165.

4. Aminoshariae A, Kulild JC. Evidence-based recommendations for antibiotic usage to treat endodontic infections and pain. A systematic review of randomized controlled trials. J Am Dent Assoc 2016; 17: 3-6.

5. Andersson L, Andreasen JO, Day P, et al. International Association of Dental Traumatology guidelines for the management of traumatic dental injuries: 2 . Avulsion of permanent teeth. Dent Traumatol 2012; 28: 88-96.

6. Arteagoitia I, Ramos E, Santamaria G, et al. Amoxicillin/clavulanic acid 2000/125 mg to prevent complications due to infection following completely bone-impacted lower third molar removal: a clinical trial. Oral Surg Oral Med Oral Pathol Oral Radiol 2015; 119: 8-16.

7. Asi KS, Gill AS, Mahajan S. Postoperative bacteremia in periodontal flap surgery, with and without prophylactic antibiotic administration: a comparative study. J Indian Soc Periodontol 2010; 14: 18-22.

8. Assem NZ, Alvez MLF, Lopes AB, et al. Antibiotic therapy as an adjunct to scaling and root planing in smokers: a systematic review and meta-analysis. Braz Oral Res 2017; 31: e67.

9. Bamias A, Kastritis E, Bamia C, et al. Osteonecrosis of the jaw in cancer after treatment with bisphosphonates: incidence and risk factors. J Clin Oncol 2005; 23: 8580-8587.

10. Bortoluzzi MC, Capella DL, Barbieri T, et al. A single dose of amoxicillin and dexamethasone for prevention of postoperative complications in third molar surgery: a randomized, double-blind, placebo controlled clinical trial. J Clin Med Res 2013; 5: 26-33.

11. Caton JG, Armitage G, Berglundh T, et al. A new classification scheme for periodontal and peri-implant diseases and conditions - introduction and key changes from the 1999 classification. J Periodontol 2018; 89 Suppl 1: S1-S8.

12. Cherry WR, Lee JY, Shugars DA, et al. Antibiotic use for treating dental infections in children. JADA 2012; 143: 31-38.

13. Chrcanovic BR, Albrektsson T, Wennerberg A. Prophylactic antibiotic regimen and dental implant failure: a meta-analysis. J Oral Rehabil 2014; 41: 941-956.

14. Critser G. Generation Rx: How prescription drugs are alerting American lives, minds and bodies. Houghton Mifflin, New York 2005; 106-110. 
15. Dakic A, Boillot A, Colliot C, et al. Detection of Porphyromonas gingivalis and Aggregatibacter actinomycetemcomitans after systemic administration of amoxicillin plus metronidazole as an adjunct to non-surgical periodontal therapy: a systematic review and meta-analysis. Front Microbiol 2016; 19: 1277.

16. Danda AK, Ravi P. Effectiveness of postoperative antibiotics in orthognathic surgery: a metaanalysis. J Oral Maxillofac Surg 2011 69: 2650-2656.

17. Del Fabrro M, Corbella S, Sequeira-Byron P, et al. Endodontic procedures for retreatment of periapical lesions. Cochrane Database Syst Rev 2016; 19: CD005511.

18. Diangelis AJ, Andreasen JO, Ebeleseder KA, et al. International Association of Dental Traumatology guidelines for the management of traumatic dental injuries: 1 . Fractures and luxations of permanent teeth. Dent Traumatol 2012; 28: 2-12.

19. Esposito M, Grusovin MG, Worthington HV. Interventions for replacing missing teeth: antibiotics at dental placement to prevent complications (review). Cochrane Database Syst Rev 2013; 31: CD004152.

20. European Society of Cardiology. 2015 ESC Guidelines for the management of infective endocarditis. Eur Heart J 2015; 36: 3075-3123.

21. Flynn TR. What are the antibiotics of choice for odontogenic infections, and how long should the treatment course last? Oral Maxillofac Surg Clin North Am 2011; 23: 519.

22. Glenny AM, Oliver R, Roberts GJ, et al. Antibiotics for the prophylaxis of bacterial endocarditis in dentistry. Cochrane Database Syst Rev 2013; 10: CD003813.

23. Gluck B. The advisability of immediate extraction in cases of swelling. Dental Items Interest 1939; 61: 225.

24. Guerrero JS. Use of prophylactic antibiotic therapy in oral surgical procedures: a critical review. J Calif Dent Assoc 2008; 36: 943-950.

25. Habib G, Lancellotti P, Iung B. 2015 ESC Guidelines on the management of infective endocarditis: a big step forward for an old disease. Heart 2016; 102: 992-994.

26. Hallström H, Persson GR, Lindgren S, Renvert S. Open flap debridement of peri-implantitis with or without adjunctive systemic antibiotics - a randomized clinical trial. J Clin Periodontol 2017; 44: 1285-1293.

27. Heim N, Faron A, Wiedemeyer V, et al. Microbiology and antibiotic sensitivity of head and neck space infections of odontogenic origin. Differences in inpatient and outpatient management. J Craniomaxillofac Surg 2017; 45: 1731-1735.

28. Hryniewicz W, Kulig J, Ozorowski T, et al. Stosowanie antybiotyków w profilaktyce okołooperacyjnej. Narodowy Instytut Leków, Warszawa 2011.

29. Horliana AC, Chambrone L, Foz AM, et al. Dissemination of periodontal pathogens in the bloodstream after periodontal procedures: a systematic review. PLoS One 2014; 9: e98271.

30. Hought RT, Fitzgerald BE, Latta JE, Zallen RD. Ludwig's angina: report of two cases and review of the literature from 1945 to January 1979. J Oral Surg 1980; 38: 849.

31. Hullah E. Antimicrobials - antibiotics. Wray D (ed.). In: Essential dental therapeutics. Wiley Blackwell, Oxford 2018: 31-40.

32. Igoumenakis D, Glannakopoulos NN, Parara E, et al. Effect of causative tooth extraction on clinical and biological parameters of odontogenic infection: a prospective clinical trial. J Oral Maxillofac Surg 2015; 73: 1254-1258.

33. Johri A. Should teeth be extracted immediately in the presence of acute infection? Oral Maxillofac Surg Clin North Am 2011; 23: 507.

34. Jepsen S, Berglund T, Zitzmann NU. Primary prevention of periimplantitis: managing peri-implant mucositis. J Clin Periodontol 2015; 42 Suppl 16: S152-7.

35. Kreutzer K, Storck K, Weitz J. Current evidence regarding prophylactic antibiotics in head and neck and maxillofacial surgery. Biomed Res Int 2014; 879437.

36. Kumari S, Mohanty S, Sharma P, et al. Is the routine practice of antibiotic prescription and microbial culture and antibiotic sensitivity testing justified in primary maxillofacial space infection patients? A prospective, randomized, comparative clinical study. J Craniomaxillofac Surg 2018; 46: 446-452.

37. Kuriyama T, Lewis MA, Williams DW. Infections of the oral and maxillofacial region. In: Andresson L, Kahnberg KE, Pogrel MA. Oral and maxillofacial surgery. Wiley-Blackwell, Oxford 2010: 465-578.

38. Lee CT, Huang YW, Liang Z, Weltman R. Prevalences of periimplantitis and peri-implant mucositis: systematic review and meta-analysis. J Dent 2017; 62: 1-12.

39. Lewis MA. Why we must reduce dental prescription of antibiotics: European Union Antibiotics Awareness Day. Br Dent J 2009; 205: 537-538.

40. Lindeboom JAH, van den Akker HP. A prospective placebo-controlled double-blind trial of antibiotic prophylaxis in intraoral bone grafting procedures: a pilot study. Oral Surg Oral Med Oral Pathol Oral Radiol Endod 2003; 96: 669-672.

41. Lindeboom JAH, Tuk JG, Kroon FK, van den Akker HP. A randomized prospective controlled trial of antibiotic prophylaxis in intraoral bone grafting procedures: single-dose clindamycin versus 24-hour clindamycin prophylaxis. Mund Kiefer Gesichts Chir 2005; 9: 384-388.

42. Lindeboom JAH, Franken JW, Valkenburg P, van den Akker HP. The role of preoperative antibiotic administration in periapical endodontic surgery. Int Endod J 2005; 38: 877-881.

43. Lindeboom JA, Frenken JW, Tuk JG, Kroon FH. A randomized prospective controlled trial of antibiotic prophylaxis in intraoral bone-grafting procedures: preoperative single dose penicillin versus preoperative single dose clindamycin. Int J Oral Maxillofac Surg 2006; 35: 433-436.

44. Lodi G, Figini L, Sardella A, et al. Antibiotics to prevent complications following tooth extractions. Cochrane Database Syst Rev 2012; 11: CD003811.

45. Löfmark S, Jernberg C, Jansson JK, Edlund C. Clindamycin-induced enrichment and long-term persistence of resistant Bacteroides spp. and resistance genes. J Antimicrob Chemother 2006; 58: 1160-1167.

46. Malmgren B, Andreasen JO, Flores MT, et al. International Association of Dental Traumatology guidelines for the management of traumatic dental injuries: Injuries in the primary dentition. Dent Traumatol 2012; 28: 174-82.

47. Martin MV, Kanatas AN, Hardy P. Antibiotic prophylaxis and third molar surgery. Br Dent J 2005; 198: 327-330.

48. Martins JR, Hagas OL Jr, Velasquez BD, et al. The use of antibiotics in odontogenic unfections: what is the best choice? A systematic review. J Oral Maxillofac Surg 2017; 75: 2606.e1-2606.e11.

49. Mauceri R, Campisi G, Matranga D, et al. The role of antibiotic prophylaxis in reducing bacterial contamination of autologous bone graft collected from implant site. Biomed Res Int 2017; 2175019.

50. Miller C. Decisions and antibiotic use: more questions and some answers. Oral Surg Oral Med Oral Pathol Oral Radiol Endod 2010; 110: 1-3.

51. Mohan RR, Doraswamy DC, Hussain AM, et al. Evaluation of the role of antibiotics in preventing postoperative complication after routine periodontal surgery: a comparative clinical study. J Indian Soc Periodontol 2014; 18: 205-212.

52. Mombelli A, Samaranyake LP. Topical and systemic antibiotics in the management of periodontal diseases. Int Dent J 2004; 54: 3-14.

53. Montefusco V, Gay F, Spina F, et al. Antibiotic prophylaxis before dental procedures may reduce the incidence of osteonecrosis of the jaw in patients with multiple myeloma treated with bisphosphonates. Leuk Lymph 2008; 49: 2156-2162.

54. Oberoi SS, Dhingra C, Sharma G, Sardana D. Antibiotics in dental practice: how justify are we. Int Dent J 2015; 65: 4-10.

55. Olczak-Kowalczyk D, Karolak-Żak D, Tymińska D, KrasuskaSławińska D. Antybiotyki w stomatologii dziecięcej. Nowa Stom 2014; 3: 131-137.

56. Oswal S, Ravindra R, Sinha A, Manjunath S. Antibiotics in periodontal surgeries: a prospective randomised cross over clinical trial. J Indian Soc Periodontol 2014; 18: 570-574. 
57. Pallasch TJ. Antibiotic resistance. Dent Clin North Am 2003; 47: 623-639.

58. Pallasch TJ. Principles of antibiotic therapy. In: Yagiela JA, Dowd FJ Johnson B, Mariotti A, Neidle EA (eds.). Pharmacology and Therapeutics for Dentistry. Mosby Elsevier, St. Louis 2011; 579599.

59. Palmer NOA. Antimicrobial resistance and antibiotic prescribing in dental practice. Dent Update 2016; 43: 954-960.

60. Park J, Tennant M, Walsh LJ, Kruger E. Is there a consensus on antibiotic usage for dental implant placement in healthy patients? Aust Dent J 2018; 63: 25-33.

61. Perdikaris G, Pefanis A, Giamarellou E. Prophylactic and therapeutic use of antibiotics in dentistry. In: Fragiskos DF (ed.). Oral Surgery. Springer, Heidelberg 2007: 349-364.

62. Peterson LJ. Antibiotic prophylaxis against wound infections in oral and maxillofacial surgery. J Oral Maxillofac Surg 1990; 48: 617-620.

63. Qian J, Wennerberg A, Albrektsson T. Reasons for marginal bone loss around oral implants. Clin Implant Dent Rel Res 2012; 14: 792-807.

64. Rademacher WM. Antibiotic prophylaxis is not indicated prior to dental procedures for prevention of periprosthetic infections. Acta Orthopaedica 2017; 88: 568-574.

65. Ramos E. Do systemic antibiotics prevent dry socket and infection after third molar extraction? A systematic review and meta-analysis. Oral Surg Oral Med Oral Pathol Oral Radiol 2016 122: 403-425.

66. Rams TE, Degener JE, van Winkelhoff AJ. Antibiotic resistance in human chronic periodontitis microbiota. J Periodontol 2014 85: $160-169$

67. Roberts GJ. Dentists are innocent! "Everyday" bacteremia is the real culprit: a review and assessment of the evidence that dental surgical procedures are a principal cause of bacterial endocarditis in children. Pediatr Cardiol 1999; 20: 317-325.

68. Saia G, Blandamura S, Bettini G, et al. Occurrence of bisphosphonate-related osteonecrosis of the jaw after surgical tooth extraction. J Oral Maxillofac Surg 2010; 68: 797-804.

69. Schwarz F, Schmucker A, Becker J. Efficacy of alternative or adjunctive measures to conventional treatment of peri-implant mucositis and peri-implantitis: a systematic review and meta-analysis. Int J Implant Dent 2015; 1: 22.

70. Segura-Egea JJ, Gould K, Sen BH, et al. European Society of Endodontology position statement: the use of antibiotics in endodontics. Int Endod J 2017; 51: 20-25.

71. Soares GMS, Mendes JAV, Silva MP, et al. Metronidazole alone or with amoxicillin as adjuncts to non-surgical treatment of chronic periodontitis: a secondary analysis of microbiological results from a randomized clinical trial. J Clin Periodontol 2014; 41: 366-376.

72. Souto MLS, Rovai ES, Ganhito JA, et al. Efficacy of systemic antibiotics in nonsurgical periodontal therapy for diabetic subjects: a systematic review and meta-analysis. Int Dent J 2018; 68: 207-220.

73. Tan SK, Lo J, Zwahlen RA. Perioperative antibiotic prophylaxis in orthognathic surgery: a systematic review and meta-analysis of clinical trials. Oral Surg Oral Med Oral Pathol Oral Radiol Endod 2011; 112: 19-27.

74. Uçkay I, Pittet D, Bernard L, et al. Antibiotic prophylaxis before invasive dental procedures in patients with arthroplasties of the hip and knee. J Bone Joint Surg Br 2008; 90: 833-838.

75. Verdugo F. Risk of superinfection in peri-implantitis after systemic broad spectrum antibiotics. Int Periodontics Restorative Dent 2018; 38: 443-450.

76. Wainwright J. Anesthesia and immediate extraction in the presence of swellings of the jaws. Dental Items Interest 1940; 62: 849.

77. Watters W 3rd, Rethman MP, Hanson NB. Prevention of orthopaedic implant infection in patients undergoing dental procedures. J Am Acad Orthop Surg 2013; 21: 180-189.

78. Williams AC. Ludwig's angina. Surg Gynecol Obstet 1940; 70: 140

79. Williams AC, Guralnick WC. The diagnosis and treatment of Ludwig's angina: report of twenty cases. N Engl J Med 1943; 8: 228.
80. Yingling NM, Byrne BE, Hartwell GR. Antibiotic use by members of the American Association of Endodontists in the year 2000: report of a national surgery. J Endod 2002; 28: 396-404.

81. Zandbergen D, Slot DE, Niederman R, Van der Weijden FA. The concomitant administration of systemic amoxicillin and metronidazole compared to scaling and root planing alone in treating periodontitis: a systematic review. BMC Oral Health 2016; 29: 27. 